PontIFícIA UNIVERSIDADE CATÓLICA dO RIO DE JANEIRO

\author{
Análise dos fatores que influenciam o \\ consumidor do Rio de Janeiro a escolher \\ entre livros impressos ou digitais para lazer
}

Natalia Mira Picorelli e Sousa

Trabalho de Conclusão de Curso

Centro de CIÊNCIAS SOCIAIS - CCS

DEPARTAMENTO DE ADMINISTRAÇÃO

Graduação em Administração de Empresas 


\section{Análise dos fatores que influenciam o consumidor do Rio de Janeiro a escolher entre livros impressos ou digitais para lazer}

Trabalho de Conclusão de Curso

Trabalho de Conclusão de Curso, apresentado ao programa de graduação em Administração da PUC-Rio como requisito parcial para a obtenção do titulo de graduação em Administração.

Orientadora: Renata Céli 


\section{Agradecimentos}

Primeiramente, gostaria de agradecer a Deus, por sempre olhar por mim e iluminar meus caminhos.

À minha mãe, meu maior amor e orgulho, por estar sempre ao meu lado, confiando, apoiando e me incentivando a lutar pelos meus sonhos e nunca deixar de acreditar.

Aos meus queridos avós, motivo de inspiração e orgulho, por estarem sempre ao meu lado, permitindo-me acreditar e realizar meus sonhos.

E, por fim, a todos aqueles que dividiram comigo essa jornada e me apoiaram ao longo dos anos, obrigada pela força e incentivo. 


\section{Resumo}

Picorelli, Natalia. Céli, Renata. Análise dos fatores que influenciam o consumidor do Rio de Janeiro a escolher entre livros impressos ou digitais para lazer. Rio de Janeiro, 2015. Trabalho de Conclusão de Curso - Departamento de Administração. Pontifícia Universidade Católica do Rio de Janeiro.

Este estudo visa compreender o comportamento do consumidor frente às mudanças do mercado literário, analisando os fatores que influenciam o seu processo decisório ao optar por livros impressos ou livros digitais. Por meio de entrevistas em profundidade com leitores habituais do Rio de Janeiro, foi possível identificar hábitos de leitura e características do processo decisório, como: motivadores da compra de livros, fontes de informações utilizadas pelos leitores para a tomada de decisão e os principais atributos analisados. Perceberam-se também as preferências dos leitores em relação aos livros impressos e digitais, identificando pontos positivos e negativos. Os resultados demonstraram que os principais motivadores da compra são a busca pelo entretenimento e conhecimento, considerados através de indicações de amigos ou familiares, sites e na própria livraria, onde se analisa principalmente a sinopse e capa. Quanto à preferência dos livros, os impressos demonstraram ser a forma favorita de leitura, pelo seu poder de envolvimento e características materiais.

\section{Palavras- chave}

Comportamento do Consumidor; Processo Decisório de Compra; Mercado Literário; Livros Digitais; E-books; Livros Impressos. 


\begin{abstract}
Picorelli, Natalia. Céli, Renata. An analysis of the factors that influence Rio de Janeiro's consumers to choose between printed books and e-books.. Rio de Janeiro, 2015. Final Project - Business Departament Pontifícia Universidade Católica do Rio de Janeiro.
\end{abstract}

The paper aims to understand the consumers' behavior regarding the changes on the world of literature, analyzing the factors that influence their decision-making process while choosing between printed books or e-books. After a series of in-depth interviews with regular readers from Rio de Janeiro, it was possible to identify reading habits and characteristics on their decision-making process, such as: what motivates them to buy the books, sources where the readers gather informations that help them make their decisions and the main attributes. It was also possible to notice the readers' preferences when it comes to the printed and digital books, pointing out their positive and negative aspects. The results show that thirst for knowledge and entertainment are their main motivation while looking for a book, after either a friend's/family member's/website or bookstore recommendation, and the main points analyzed are the synopsis and book covers. Regarding the book preferences, the printed ones were a definite favorite as it holds the power to involve the reader and also because of material motives

Key-words

Consumer Behavior; Purchase Decision Process; Literary Market; E-books; Printed Books. 


\section{Sumário}

1 O tema e o problema de estudo 8

1.1. Introdução 8

1.2. Objetivo do estudo 9

1.3. Objetivos intermediários do estudo 9

$\begin{array}{ll}\text { 1.4. Delimitação do estudo } & 9\end{array}$

$\begin{array}{ll}\text { 1.5. Justificativa e relevância do estudo } & 10\end{array}$

2 Revisão de literatura 11

2.1. A evolução do livro 11

2.2. O Livro Digital 14

2.3. Comportamento do Consumidor 15

$\begin{array}{ll}\text { 2.3.1. Motivação } & 17\end{array}$

2.3.2. Comportamento de Compra e Processo Decisório 19

3 Métodos e procedimentos de coleta e de análise de dados do estudo 24

3.1. Tipo de Pesquisa 24

3.2. Fontes de informação selecionadas para coleta de dados no estudo25

3.3. Procedimentos e instrumentos de coleta de dados utilizados no estudo 25

3.4. Formas de tratamento e análise dos dados coletados para o estudo27

$\begin{array}{ll}\text { 3.5. Limitações do Método } & 27\end{array}$

4 Apresentação e análise dos resultados 29

4.1. Perfil dos Entrevistados 29

4.2. Frequência de Leitura 30

4.3. Comportamento da Compra 31

4.3.1. Reconhecimento da Necessidade 31

4.3.2. Busca de Informações e Avaliação de Alternativas 34

4.3.3. Hábito de Leitura 36

4.4. Livros Impressos x Livros Digitais 39 
5 Conclusões e recomendações para novos estudos

6 Referências Bibliográficas

Anexo 1

\section{Lista de figuras}

Figura 1: Hierarquia das Necessidades de Maslow

Figura 2: Modelo de Processo de Compra do Consumidor

\section{Lista de Tabelas}

Tabela 1: Perfil dos Entrevistados

Tabela 2: Pontos positivos dos livros impressos e digitais

41

Tabela 3: Pontos negativos dos livros impressos e digitais 


\section{0 tema e o problema de estudo}

\subsection{Introdução}

O mercado literário, que conta hoje com 88,2 milhões de leitores no país, de acordo com a pesquisa Retratos da Leitura no Brasil, encomendada pela Fundação Pró-Livro e pelo Ibope Inteligência de 2012, tem vivenciado mudanças ao longo dos últimos anos. O surgimento dos e-books, ou livros digitais, e a sua crescente difusão fazem com que o cenário desse setor se altere e entre na era digital. Entretanto, diferentemente de outros setores, os livros impressos não foram extintos, sendo ainda o formato de leitura preferido no país, segundo a matéria "O avanço dos livros digitais", de Juliana Britto, publicada pela ABRALE (Associação Brasileira dos Autores de Livros Educativos) em 2013.

Contudo, de acordo com dados da pesquisa "Produção e Venda do Setor Editorial”, feita em 2014 pela Fundação Instituto de Pesquisas Econômicas (Fipe), o mercado editorial no Brasil faturou com os e-books $R \$ 3,8$ milhões no ano de 2012 e esse número cresceu para $R \$ 12,7$ milhões em 2013. Esses dados foram feitos com 217 editoras, ou seja, $72 \%$ do mercado.

Ainda de acordo com a pesquisa, em relação aos livros impressos os números são bem diferentes. O faturamento registrado foi de $R \$ 5,3$ bilhões, também em 2013, tendo um aumento de 7,52\% em relação a 2012. Contudo, ao descontar a inflação do período (5,91\%), o aumento real foi de $1,52 \%$.

Apesar de os números se mostrarem positivos para os livros digitais, e a tecnologia estar cada dia mais presente no cotidiano das pessoas, ainda existem questionamentos quanto à aceitação dos leitores aos textos em formatos virtuais.

De acordo com uma matéria feita pelo Portal Puc-Rio Digital (2013) sobre a transformação do modo de ler, para alguns, os livros digitais vão ganhar cada vez mais espaço e são melhores pela sua praticidade e interatividade. Já para outros, a leitura é melhor quando feita com os textos em mãos, sem distrações e onde se possa "sentir o livro", sem se perder esse contato. E há ainda aqueles que acreditam que existe espaço para os dois tipos de textos. 
O entendimento do comportamento do consumidor, principalmente no seu processo decisório e motivação de compra, é de extrema importância para as empresas (SOLOMON, 2011), e assim também o é para quem atua neste setor, sobretudo editoras brasileiras. Este determina o futuro e prevê se os grandes investimentos que são necessários para entrar no mercado de e-books serão válidos.

Além disso, é importante analisar a transformação desse comportamento frente a esse novo cenário onde a tecnologia se encontra cada vez mais presente no cotidiano das pessoas (Britto, 2013) e entender até que ponto o uso de smartphones e tablets altera a percepção, motivação e atitudes dos consumidores, alterando seu modo de ler.

Deste modo, cabe a seguinte questão: Quais são os principais fatores que influenciam o consumidor a escolher entre livros impressos ou digitais?

\subsection{Objetivo do estudo}

O objetivo do presente estudo é entender quais são os fatores que influenciam a escolha dos consumidores entre livros impressos ou digitais.

\subsection{Objetivos intermediários do estudo}

Para auxiliar no alcance do objetivo final do estudo, foram desenvolvidos objetivos intermediários, a saber:

- Investigar os hábitos de leitura do consumidor

- Investigar o processo decisório do consumidor em relação à compra de livros

- Analisar as preferências mais relevantes dos leitores para a escolha de livros impressos e digitais

- Investigar pontos positivos e negativos dos livros impressos e digitais

\subsection{Delimitação do estudo}

O estudo busca analisar o comportamento do consumidor frente à tomada de decisão da compra de livros, delimitando-se à moradores da cidade do Rio de Janeiro, que possuem idade na faixa etária de 18 a 40 anos e que tenham o hábito de ler e comprar livros para lazer. 
Serão consideradas pessoas que tenham lido pelo menos um livro nos últimos seis meses, sendo estes, obras literárias, como romances, contos, biografias, fantasias, entre outros.

Além disso, serão analisados aqueles que têm o hábito de comprar livros, tanto impressos, quanto digitais, por meio de lojas físicas ou virtuais.

\subsection{Justificativa e relevância do estudo}

O estudo é importante para entender os fatores que influenciam o processo decisório dos consumidores do mercado literário, dadas as opções de livros disponíveis atualmente, facilitando o direcionamento de esforços principalmente da área de marketing de empresas relacionadas.

É interessante para as editoras brasileiras e livrarias, por exemplo, pois elas podem entender qual é a preferência dos consumidores desse mercado, e indicar possíveis tendências em relação ao futuro do setor.

Devido os avanços tecnológicos, é necessário entender os consumidores desse setor e acompanhar sua resposta frente às mudanças que estão ocorrendo e que podem mudar, definitivamente, a forma de ler.

Além disso, esse estudo abordará um tema ainda pouco difundido e analisado academicamente. Existem, hoje, poucos artigos no Brasil que tratem sobre o comportamento do consumidor no processo de compra de livros. 


\section{Revisão de literatura}

Neste capítulo são apresentados e discutidos aspectos conceituais e estudos relacionados ao comportamento do consumidor e seu processo decisório de compra e o mercado literário.

\subsection{A evolução do livro}

O homem sempre utilizou ferramentas e materiais para marcar sua passagem pelo mundo (CALDEIRA, 2002). Segundo a publicação "Do papiro ao papel manufaturado", de Caldeira (2002), diversos povos já registravam seus conhecimentos em materiais diversos, como os indianos, que utilizavam folhas de palmeiras, ou os romanos que utilizavam tábuas feitas de madeira para fazer a escrita e os registros.

No Egito Antigo, por volta de 2200 a.C., os egípcios desenvolveram a tecnologia do papiro. Nesta época, os escribas eram aqueles que fabricavam os textos e, portanto, aqueles que praticavam a atividade da escrita. Tais documentos eram guardados em rolos que chegavam a quase 20 metros. (CALDEIRA, 2002).

De acordo com Sousa (2015), por volta do século $X$ a.C., surgiram os pergaminhos, feitos normalmente de pele de bovinos e bem mais resistentes. Esse salto na evolução foi essencial para a preservação de diversos textos da Antiguidade, como exemplo a Bíblia Sagrada. Além disso, é válido ressaltar, que até este momento, os "livros" eram vistos como obras de arte por terem sua produção feita toda à mão, sem nenhum componente químico e não havendo a reprodução rápida e mecânica.

Ainda segundo Sousa (2015), o papel como conhecemos foi inventado na China, por volta do século 2 d.C. Sua produção consistia na mistura de fibras feitas de plantas, tecidos velhos e fragmentos de redes de pesca com água, formando uma pasta que ao ser prensada e seca formava o papel. Entretanto, a descoberta levou anos até que fosse divulgada e passada aos demais povos. Foi introduzida na Europa em 1150, pelos Árabes, depois da conquista da Península Ibérica. 
No período medieval a importância do papel cresceu, sendo a principal forma de divulgação literária. Entretanto, segundo o livro "A questão dos Livros: Passado, Presente e Futuro" de Robert Darnton (2010), antigamente os livros sofriam com a desigualdade das sociedades e só uma parte que possuía "privilégios" tinha acesso a eles, principalmente os clérigos.

Contudo, em 1454, o ourives alemão Johannes Gutenberg contribuiu para um novo salto na evolução dos livros. Através da sua invenção da prensa de tipos móveis, onde letras de chumbo eram colocadas lado a lado, formando palavras e frases e prensadas em papel, formando a primeira "impressora", foi possível dinamizar o processo de fabricação de livros, possibilitando sua popularização pela capacidade de impressão em massa. (LINARDI, 2008). O grande marco foi a impressão da Bíblia de Gutenberg, de 42 linhas, surgindo então, a invenção da tipografia, que modificou a realidade da informação escrita, deixando de ser exclusividade das classes privilegiadas e expandindo-se ao resto da Europa. (LINARDI, 2008)

A partir do século XIX, com o barateamento dos custos de produção, o livro realmente atravessou mares, e conseguiu aumentar seu alcance e divulgação. (SOUSA, 2015,). Pode-se dizer que o livro é um dos inventos mais grandiosos do homem, principalmente, pelo seu poder de armazenar e passar conhecimento. Pode-se falar também, que ainda hoje, são considerados um dos principais meios de comunicação escrita, seja pelas obras literárias ou científicas. Portanto, com o passar dos anos, a conscientização de que os livros deveriam ser um bem de todos ganhou espaço e a abrangência dos livros também. (SANTOS, 2010).

Com o desenvolvimento das tecnologias e o avanço dos recursos multimídias, os livros também entraram na era digital. A disponibilização de livros a um número cada vez maior de pessoas está diretamente ligada com esses avanços. (DARTON, 2010). Como exemplo, temos a venda online de livros, ou seja, diversas livrarias passaram a contar com lojas online (PORTO; MIOTTO, 2008).

Porém, a nova revolução da historia literária, foi a digitalização de livros. Esse movimento começou, por volta de 1971, influenciado pelo "Projeto Gutenberg", que tem como filosofia "disponibilizar informação, livros e outros materiais ao público em geral em formas que a vasta maioria dos computadores, programas e pessoas possam facilmente ler, usar, citar e pesquisar." (GUTENBERG, 2015).

De acordo com Reimão (2004): 
"No século $X X$, a expansão e o desenvolvimento dos computadores propiciaram, entre outras inovações, 0 surgimento do livro eletrônico: livros digitalizados, transmitidos por meio de redes virtuais ou disponíveis em bases eletrônicas, e lidos em uma tela de computador ou apetrechos análogos" (p. 1).

Os livros eletrônicos receberam o nome de e-books, onde o "e" na frente do nome diz respeito a objetos eletrônicos (BOTTENTUIT JUNIOR; COUTINHO, 2007).

Contudo, na época do nascimento dos e-books, as primeiras experiências violaram os direitos dos autores, tendo suas obras hackeadas e expostas na internet para milhares de pessoas sem que houvesse custo. Hoje, as formas de obtenção de livro digitais são mais seguras e prezam pela valorização dos direitos autorais, entretanto não são totalmente invioláveis (PORTELLA, 2003).

Mais tarde, por volta de 1998, são lançados softwares de leitura, os ereaders. Assim, os e-books, que são os livros eletrônicos, passam a ganhar espaço e passam a atender as demandas dos adeptos às tecnologias e do mundo virtual, como principalmente os jovens (MESQUITA; CONDE, 2008). Um dos principais diferenciais que os e-readers trouxeram foi a comodidade de poder acessar vários livros em um único aparelho.

Reimão (2004) menciona que com o surgimento dos e-books, o meio acadêmico começou a produzir artigos e livros tentando prever o fim dos livros tradicionais (livros impressos).

Por outro lado, autores ressaltam que:

"Apesar de ser bastante divulgado em países como os Estados Unidos e Inglaterra, a utilização desta modalidade de leitura ainda é pouco utilizada em grande parte do mundo constituindo por conseguinte uma temática emergente, ainda pouco investigada mas com enorme potencial em especial se associada a dispositivos móveis que podem promover a popularização de uma prática que, nos dias de hoje, continua restrita aqueles que tem acesso à Internet e que dominam a utilização das tecnologias" (BOTTENTUIT JUNIOR; COUTINHO, 2007, p. 106). 


\subsubsection{Livro Digital}

Não só os livros estão entrando na era digital, as músicas, filmes e revistas também estão sendo adaptados para novos formatos com o desenvolver das tecnologias. Essas mudanças são significativas para a sociedade pela capacidade de evolução, com o objetivo de sempre melhorar. Além, é claro, de atender a muitos adeptos do mundo virtual. (BRITTO, 2013)

Como foi visto anteriormente, a nova evolução dos livros foi a sua digitalização e em seguida a criação de dispositivos que possibilitavam a sua leitura de forma móvel e prática, os e-readers. (POSSARI, 2014).

O objetivo dos e-readers é oferecer ao usuário a sensação de estar lendo um livro impresso. Para isso, toda a criação desses leitores foi voltada a tentar reproduzir, de forma mais próxima possível, a página de um livro. Eles utilizam uma tela especifica que tem iluminação adequada para a leitura, não afetando tanto a vista, e uma tinta eletrônica que imita o papel. (PREMISSAS, 2010).

Além disso, os dispositivos oferecem outras características como a possibilidade de armazenamento de diversas obras em um mesmo aparelho. Por exemplo, no Kindle é possível armazenar até 1500 títulos. (PREMISSAS, 2010). Outro ponto interessante é o acesso a impressões com tiragem reduzida e a conveniência na hora da compra, que pode ser feita com apenas um clique no próprio dispositivo. (MESQUITA; CONDE, 2008).

Outras vantagens percebidas pelos pesquisadores Bottenttuit e Coutinho (2007), foram a busca de termos ou palavras durante a leitura, feita na própria tela do e-reader, a interação com recursos multimídias, entre outras, sendo a acessibilidade e a praticidade dos e-books seus fatores mais atrativos (BRITTO, 2013). Contudo, foram percebidas como desvantagens, o preço dos dispositivos serem ainda bastante elevados, ter grande quantidade de informação mal estruturada, não se poder fazer anotações manuais, etc. (BOTTENTTUIT, COUTINHO, 2007)

Por mais que o crescimento do e-book seja inevitável, os livros impressos ainda estão resistindo, sendo ainda o meio de leitura preferido do país. (BRITTO, 2013) Como Darnton (2010) ressalta em seu livro, as obras impressas não necessitam de downloads ou upgrades, nem precisam ser acessadas ou conectadas. Pelo contrário, foram feitas para serem folheadas, com design que "é um prazer para os olhos" e onde a sua forma "torna o ato de segurá-lo nas mãos um deleite". (p.86) 
Enquanto existem pesquisadores que especulam sobre o futuro dos livros impressos ou digitais (REIMÃO, 2004), há aqueles que acreditam que existe espaço para ambos e os veem como ferramentas complementares (REVISTA PREMISSA, 2010).

Como falado anteriormente, segundo pesquisa a pesquisa Produção e Venda do Setor Editorial, conduzida pela Fundação Instituto de Pesquisas Econômicas (Fipe), a pedido do Sindicato Nacional de Editores e da Câmara Brasileira do Livro, foi possível perceber que o faturamento com e-books em 2013, $R \$ 12,7$ milhões, foi bem superior que o ano anterior, $R \$ 3,8$ milhões.

Entretanto, segundo a pesquisa Produção e Vendas do Setor Editorial Brasileiro em 2015, feita pelo mesmo instituto, vemos que a venda de livros digitais representa apenas $0,3 \%$ do mercado de livros impressos, de uma amostra de 195 das 773 editoras que publicam versões digitais. Apesar de não refletir exatamente a realidade, por não contar com o montante total, pode-se averiguar o baixo crescimento mercado digital no Brasil, onde as projeções esperadas apontavam um quadro mais favorável.

\subsection{Comportamento do Consumidor}

O estudo do comportamento do consumidor é mais que analisar apenas a compra ou o momento de troca entre o comprador e o produtor. De acordo com Solomon (2011, p.33):

\footnotetext{
"É o estudo dos processos envolvidos quando indivíduos ou grupos selecionam, compram, usam ou descartam produtos, serviços, idéias ou experiências para satisfazer necessidades e desejos."
}

Solomon (2011) ainda ressalta que é preciso enfatizar o processo de consumo como um todo, incluindo "as questões que influenciam o consumidor antes, durante e depois da compra" (p. 34).

Churchill e Peter (2007) complementam, dizendo que para realmente entender o comportamento do consumidor, deve-se ir além e estudar seus sentimentos e ações, além de quais são os fatores de influência que possam acarretar mudanças.

Para Churchill e Peter (2007), o comportamento dos consumidores é influenciado por três fatores principais: 
- Sociais: incluem cultura - principal influenciador dos desejos e do comportamento de um consumidor; subcultura - identificação de valores e crenças mais específica da cultura geral, como religião e nacionalidade; classe social - divisões hierárquicas da sociedade onde seus membros têm preferências similares; grupos de referência - pessoas que influenciam os sentimentos, pensamentos e ações dos indivíduos que recorrem a elas; família - principal influenciador do processo de decisão de compra do indivíduo.

- Marketing: incluem produto - estratégia de produto que afetam o comportamento do consumidor, como por exemplo sua embalagem; preço - estratégia de preço adotada; praça - tornar o produto disponível e onde os consumidores encontrarão o produto; promoção - modo como o produto se comunica com o consumidor.

- Situacionais: incluem ambiente físico - são os fatores concretos que influenciam o consumidor durante a compra, como ambiente e iluminação; ambiente social - o papel que as outras pessoas exercem no processo de compra, como comprar com uma amiga ou com o pai; tempo - hora do dia em que a compra ocorre; tarefa - razoes gerais para fazer uma compra; condições momentâneas estado de espírito e humor do indivíduo no momento da compra.

De acordo com Costa, Albuquerque e Salles (2007):

"O modelo de comportamento do comprador depende não somente de suas características (os fatores psicológicos e pessoais), mas também dos estímulos provocados tanto pelas variáveis controláveis do marketing (preço, praça, produto e promoção), quanto pelo ambiente político, cultural, tecnológico, etc. As decisões de compra são fortemente influenciadas por fatores culturais, sociais, pessoais e psicológicos, que, apesar de não poderem ser controlados pelos gestores de marketing, devem ser levados em conta para que seus produtos e serviços, também as marcas, possam atender os objetivos e 
necessidades dos consumidores-alvos. Para isto, é necessário que se entenda o papel que cada fator representa." (p. 4).

Portanto, conseguir entender o comportamento dos consumidores e saber identificar suas necessidades faz com que as empresas consigam se destacar no mercado e realmente se comunicar com seu público, atendendo seus desejos (SOLOMON, 2011).

\subsubsection{Motivação}

Para Kotler (2008), a motivação é um dos fatores psicológicos que influenciam o comportamento do consumidor. Existem dois tipos de necessidades, "biológicas oriundas de estados físicos, como a sede e a fome", e "psicológicas, causadas pela necessidade de reconhecimento, estima ou integração" (p.173).

Já para Solomon (2011, p.154), as necessidades podem ser utilitárias, ou seja, "um desejo de obter algum beneficio funcional ou prático", ou hedônicas, "uma necessidade de experiência envolvendo respostas ou fantasias emocionais". De acordo com Churchill e Peter (2007, p.148), a primeira está relacionada a "funções básicas e benefícios materiais", onde o indivíduo tende a ser "racional em suas escolhas" quando tentam satisfazê-las. Já a segunda "são relacionadas ao desejo do prazer e auto-expressão", e para atendê-las as pessoas tendem a se envolver, deixar as emoções fazerem parte do processo, não sendo sempre racionais.

Quando uma necessidade é despertada, o indivíduo tem um desejo, um motivo, e se comporta de determinada maneira impulsionado pela tensão criada para tentar satisfazê-lo. Esse impulso é o espaço entre o estado presente do consumidor, da necessidade, e o seu estado ideal, onde se alcança o desejo. Portanto, o grau de motivação de alguém é determinado pela distância entre esses dois estados (SOLOMON, 2011). Kotler e Keller (2012), ainda acrescentam que toda motivação tem um direcionamento, ou seja, selecionar uma meta ao invés de outra, e uma intensidade, ou seja, nos esforçamos mais por certos objetivos.

Sendo assim, os profissionais de marketing devem tentar passar aos clientes que seus produtos atendem às suas necessidades. Muitas vezes até despertando desejos não existentes anteriormente, ou seja, mexendo com suas 
emoções. Como, por exemplo, comprar um carro para se auto afirmar, "estar na moda" ou mesmo por lembrar memórias felizes (SOLOMON, 2011).

Além disso, para alcançar seu estado ideal, ou seja, a meta que vai the render a satisfação de suprir uma necessidade, pode-se percorrer diversas formas e caminhos. As empresas querem entender as metas para ofertar meios diferentes de chegar até ela. O objetivo é mostrar ao consumidor que o seu caminho é melhor e lhe trará resultados positivos (SOLOMON, 2011).

As necessidades de um indivíduo podem ser, muitas vezes, compartilhadas com outras pessoas. Contudo, a forma como estas serão satisfeitas são diferentes e variam de acordo com cada pessoa. Isso, porque as preferências são muito pessoais e especificas, seja o tipo de alimento, cor ou estilo de roupa, cada um vai ter desejar um tipo diferente para satisfazê-la. (SOLOMON, 2011).

Ainda para Solomon (2011), existem três níveis de necessidades, que influenciam no processo decisório dos indivíduos, são elas:

- Necessidade de associação: estar na companhia de outras pessoas;

- Necessidade de poder: controlar o ambiente;

- Necessidade de singularidade: está ligada à individualidade da pessoa.

Como falado anteriormente, cada consumidor tem preferências e desejos particulares, e, portanto, se comportam diferente de outras pessoas. Suas escolhas no processo de compra acabam por serem distintas, já que tentam suprir essas necessidades específicas (SOLOMON, 2011).

A teoria de Abraham Maslow traz outra perspectiva sobre a motivação dos consumidores. Tendo o objetivo de explicar "por que os indivíduos são motivados por determinadas necessidades em determinados momentos", definiu-se que "as necessidades humanas são dispostas em uma hierarquia, da mais urgente para a menos urgente" (KOTLER E KELLER, 2012, P.173).

Ou seja, segundo Maslow, para atender as necessidades psicológicas e biológicas, foi definida uma pirâmide dividida em cinco níveis de motivos, onde apenas se avançava na hierarquia quando se atendia a necessidade do nível anterior. (KOTLER E KELLER, 2012)

A Figura 1 apresenta a pirâmide de Maslow. 


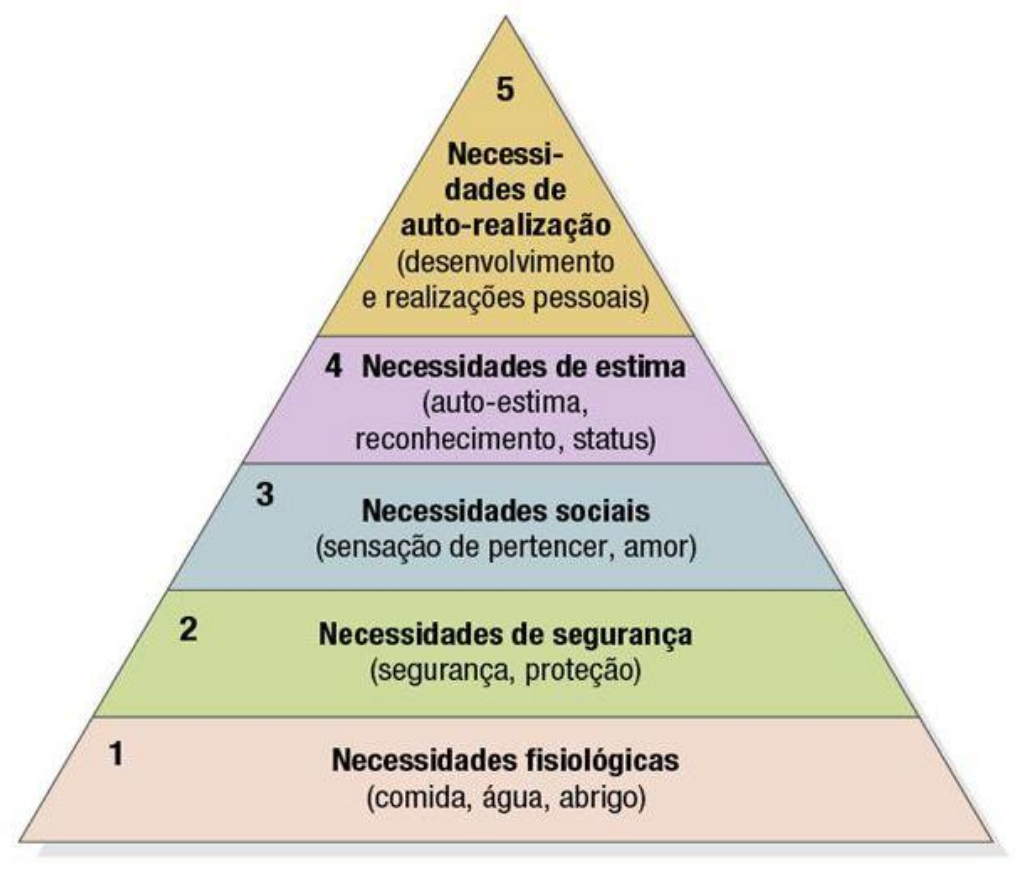

Figura 1: Hierarquia das Necessidades de Maslow

Fonte: Kotler e Keller (2012)

De acordo com Solomon (2011):

"Os profissionais de marketing adotaram essa perspectiva porque ela especifica certos tipos de benefícios que as pessoas podem esperar dos produtos, dependendo dos seus diferentes estágios de desenvolvimento mental ou espiritual ou de sua situação econômica" (p.161).

Portanto, baseando-se nisso, os consumidores percebem certos atributos dos produtos dependendo do estágio em que se encontram e do tipo de necessidade que buscam satisfazer (SOLOMON, 2011).

\subsubsection{Comportamento de Compra e Processo Decisório}

"O interesse pela compreensão de como ocorre o processo decisório do ser humano tem atraído a atenção de pesquisadores de diversas áreas" (RAMOS; SANDER; PRADO, 2013, p. 2).

Todos os dias, indivíduos tomam decisões relacionadas a aspectos de sua vida diária, escolhendo entre as diversas alternativas escancaradas à sua volta. 
Em geral, algumas decisões são mais importantes que outras fazendo com que, a quantidade de esforço colocada em cada uma seja diferente (MENDES, 1998).

De acordo com Mendes (1998):

"Algumas decisões são tomadas quase que automaticamente. Outras podem ser tomadas com 0 auxílio de poucas informações. E outras ainda, podem levar dias ou semanas e necessitar de todo um leque de informações para seja efetuada corretamente" (p. 16).

Segundo Kotler (2008), o consumidor apresenta um comportamento de compra complexo quando está muito envolvido com o produto, seja por emanar um grande risco, como alto custo, por não ser comprado com frequência ou por ser auto-afirmativo. Conforme Solomon (2011) descreve, para esse tipo de compra o consumidor irá demandar um alto esforço, pois vai buscar compreender melhor os atributos do produto, suas características e fará comparações entre diferentes modelos, tudo buscando fazer a melhor escolha.

O outro comportamento é o de compra habitual, em que há um baixo envolvimento por parte do cliente, onde a compra é feita "com pouco ou nenhum esforço consciente" (SOLOMON, 2011, p.335). Neste tipo de compra, existem poucas diferenças entre as marcas concorrentes e, na maioria das vezes, são aquisições rotineiras, onde se opta pelo que já é comum, ou seja, já estão habituados e não por fidelidade (SOLOMON, 2011).

O processo decisório de compra de um consumidor é determinado pelo envolvimento que ele desprende para determinada compra, a busca que faz por informações externas e internas, e as influências que sofre. Entretanto, considera-se que todo indivíduo passa por cinco etapas para chegar até a decisão final, são elas: "reconhecimento da necessidade, busca de informação, avaliação das alternativas, decisão de compra e avaliação de pós-compra" (CHURCHILL E PERTER, 2007), como pode ser visto na Figura 2. 


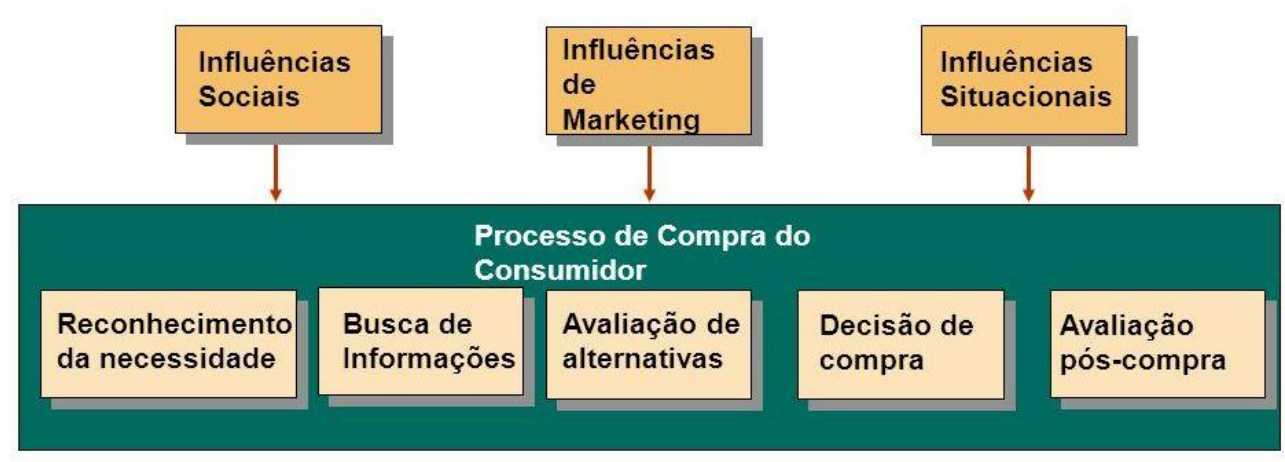

\section{Figura 2: Modelo de Processo de Compra do Consumidor}

Fonte: Churchill e Peter (2007)

A seguir, cada etapa do processo de decisão de compra dos consumidores será explicada.

- Reconhecendo as necessidades

Para Kotler e Keller (2012), o processo decisório de uma compra começa quando se percebe um problema ou necessidade, e segundo Churchill e Peter (2007), o reconhecimento dessa necessidade provém de estímulos internos ou externos, sendo o primeiro por sensações internas como fome, e o segundo por pressões do ambiente de trabalho ou necessidade de ser aceito. Os indivíduos usam a motivação como força para atender as necessidades percebidas e alcançarem o estado de satisfação desejado.

- Buscando Informações

Depois de que o consumidor reconhece uma necessidade, vai em busca de informações para tomar uma decisão a fim de satisfazê-la. (CHURCHILL E PETER, 2007). Esse processo envolve a pesquisa de dados no mercado para embasar sua decisão. Segundo Chruchill e Perter (2007), os consumidores, normalmente, utilizam cinco fontes de informação, são elas:

- Fontes internas - quando o consumidor recorre à própria memória para buscar informações, como por exemplo quando se trata de um produto que ele já conhece;

- Fontes de grupos - quando o consumidor busca informações perguntando para grupos de amigos ou familiares; 
- Fontes de marketing - o consumidor também pode buscar informações sobre um produto por meio das próprias ações de marketing da empresa, como exemplo os comerciais.

- Fontes públicas - essas fontes podem ser meios de comunicação, como jornais e revistas, quando estes não foram fornecidos pelas empresas, ou seja, reportagens e informações isentas de influências da marca. Por exemplo, classificação feita por outros consumidores;

- Fontes de experimentação - quando os consumidores experimentam ou degustam um produto, eles estão obtendo informações sobre os mesmos.

Além disso, segundo Solomon (2011), existem muito consumidores, que apreciam fazer o processo de pesquisa de informações. São aqueles que o fazem "por diversão ou porque gostam de estar atualizados sobre o que acontece no mercado", prática esta que o autor chama de pesquisa contínua. (p.337).

- Avaliando Alternativas

Após coletar as informações, os consumidores devem avaliar as alternativas encontradas para suprir sua necessidade percebida. Eles analisam cada alternativa verificando as características de cada uma e ponderando qual opção trará mais valor a sua compra, ou seja, qual delas atenderá melhor às suas expectativas. (CHURCHILL E PETER, 2007).

Kotler e Keller (2012) ressaltam também que são levados em consideração todos os atributos de cada produto e os benefícios que cada um pode entregar. Ainda segundo os autores, as atitudes e crenças de cada indivíduo são outro influenciador no seu processo de compra. Através de experiências passadas, criam-se "avaliações, sentimentos e tendências de ação, favoráveis ou não, em relação a algum objeto ou ideia" (KOTLER E KELLER, 2012; p.181 e 182). Assim, as atitudes determinam se o consumidor irá gostar ou não de certo produto, além de ter grande influência na análise das alternativas. (KOTLER E KELLER, 2012). 
- Decidindo a compra

Depois de reconhecer a necessidade e avaliar as alternativas, o consumidor deve decidir fazer ou não a compra, ponderando sobre qual produto comprar, onde comprar, quando comprar e quanto ou como pagar. (CHURCHILL E PETER, 2007).

Solomon (2011) acrescenta que para tomar a decisão de compra são os atributos determinantes, aqueles que diferem os produtos entre si, que serão mais levados em conta.

Para o presente estudo, as etapas descritas até agora são as mais importantes para entender o comportamento do consumidor durante a compra de livros.

- Avaliando a compra

Depois de efetuar uma compra, os consumidores avaliam seu resultado, ou seja, o valor recebido do produto, analisando se "ficaram satisfeitos com a experiência da compra e com o produto adquirido" (CHURCHILL E PETER, 2007, p.151). Para isso é levado em consideração o benefício recebido frente aos custos envolvidos, ou seja, expectativas versus desempenho percebido. (CHURCHILL E PETER, 2007; KOTLER, 2008)

Essa satisfação é importante para o consumidor, pois garante que seu desejo foi suprido e que se tomou a decisão certa. Já para as empresas, é importante porque quando satisfeitos, os consumidores exercem a propaganda "boca a boca", passando a amigos e familiares a boa experiência que tiveram. (CHRUCHILL E PETER, 2007). 


\section{Métodos e procedimentos de coleta e de análise de dados do estudo}

Este capítulo está dividido em cinco seções que informam, respectivamente, o tipo de pesquisa utilizado, as fontes de informação selecionadas para coleta de informações neste estudo. Depois, informa-se sobre os processos e instrumentos de coleta de dados realizados em cada etapa, com respectivas justificativas, em seguida fala-se sobre as formas escolhidas para tratar e analisar os dados coletados e, por fim, as possíveis limitações do método escolhido.

\subsection{Tipo de Pesquisa}

A presente pesquisa se caracteriza como exploratória com o intuito de entender melhor sobre os fatores que influenciam o processo decisório de compra de livros. Segundo Malhotra (2006), a pesquisa exploratória é caracterizada como flexível e não estruturada, tendo o objetivo de "explorar ou examinar um problema ou situação para proporcionar conhecimento e compreensão". (p.56).

Foram coletados dados primários, através da abordagem da pesquisa qualitativa, pelo tema do estudo ser pouco discutido e estudado, proporcionando assim uma melhor compreensão do contexto do problema. (MALHOTRA, 2002). Ainda segundo Malhotra (2006), esse tipo de pesquisa é baseado em pequenos grupos e os dados não são analisados estatisticamente.

Para coletar os dados, foi utilizada a técnica de entrevista em profundidade, que por definição de Malhorta (2002) é:

\footnotetext{
"Uma entrevista não-estruturada, direta e pessoal, em que um único respondente é testado (...) para descobrir motivações, crenças, atitudes e sensações subjacentes sobre um tópico." (p.163)
} 


\subsection{Fontes de informação selecionadas para coleta de dados no estudo}

Para investigar o tema de pesquisa, buscou-se entrevistar pessoas com perfis diferentes, para obter diferentes visões sobre um mesmo tema.

Portanto, os entrevistados foram leitores de diferentes idades e gêneros que tivessem lido pelo menos um livro nos últimos seis meses, apresentassem o costume de comprar livros literários para lazer e residissem no Rio de Janeiro.

A pesquisa foi realizada com 16 pessoas, selecionadas através do critério da conveniência.

\subsection{Procedimentos e instrumentos de coleta de dados utilizados no estudo}

Foram feitas 16 entrevistas em profundidade, realizadas de duas formas: pessoalmente e virtualmente, através de Skype e chats online de redes sociais, como o Facebook.

Segundo Nicolaci-da-Costa, Romão-Dias e Di Luccio (2008), o mundo tem mudado muito, principalmente quanto às evoluções tecnológicas. A forma como a sociedade se relaciona e está interligada é uma das principais mudanças. Sendo assim, a forma como as pesquisas na área das ciências sociais e humanas ocorrem necessitou acompanhar essas transformações e explorar novas possibilidades de obtenção de dados.

$\mathrm{Na}$ visão desses pesquisadores (2008), as pesquisas qualitativas contemporâneas seguem a seguinte premissa máxima:

"Diferentes objetivos podem requerer diferentes métodos, procedimentos e/ou instrumentos de coleta de dados, pois cada um destes apresenta um tipo de sensibilidade distinto que pode ou não ser compatível com um objetivo específico" (p.37)

De acordo com Nicolaci-da-Costa, Romão-Dias e Di Luccio (2008), com essa nova realidade virtual que se instalou, grande parte das conversas e interações interpessoais migraram para ambientes virtuais pela conectividade da internet. Essas interações se dão tanto por espaços de tempos indeterminados, como instantaneamente. Sendo assim, foi possível caminhar para uma nova forma de coletar dados. 
Sendo assim, ainda segundo os autores (2008), "as entrevistas on-line são adequadas sempre que essa condição básica for satisfeita e o objetivo da pesquisa permitir seu uso" (p.39).

Todas as entrevistas realizadas virtualmente foram feitas com 0 consentimento dos entrevistados, que estavam familiarizados com o meio utilizado, e na maioria das vezes, preferiram entrevistas on-line a presenciais. Além disso, o método facilitou a obtenção dos dados por diminuir as distâncias entre o entrevistador e entrevistado, quando não foi possível o encontro face-aface. Já as entrevistas feitas pessoalmente, foram realizadas em ambientes neutros e agradáveis, para manter um clima informal durante a conversa.

Foi elaborado um roteiro semi-estruturado de perguntas abertas, baseado na revisão de literatura do presente estudo, que foi utilizado como guia para conduzir as entrevistas. O roteiro pode ser visto em Anexo.

A entrevista foi iniciada com uma breve explicação sobre o tema abordado no estudo. Em seguida foram feitas perguntas referente ao perfil da pessoa, depois, com o intuito de certificar que aquele entrevistado realmente se enquadrava nos requisitos pré-estabelecidos, foi perguntado sobre a frequência de leitura. Na sequência, foram perguntadas questões sobre hábitos de leitura, preferências, motivações e percepções sobre livros digitais e impressos.

No caso das entrevistas feitas pessoalmente, manteve-se a estruturação e dinâmica detalhada acima. Foi usado um gravador, com a permissão prévia do entrevistado, para registrar toda a conversa, que depois foi transcrita fielmente para um arquivo de texto para ser melhor analisada.

Mesmo utilizando o esboço de roteiro, as perguntas foram sendo feitas de acordo com as respostas dos entrevistados. Foram acrescentadas perguntas cabíveis durante a conversa, de acordo com o que era respondido, de modo a explorar melhor o testemunho dos entrevistados. Utilizando a técnica de sondagem foi possível também obter respostas significativas, em que as motivações e preferências eram mais detalhadas (MALHOTRA, 2002). Dessa forma, foi possível entender melhor os fatores que levam os consumidores a escolherem entre livros digitais ou físicos. 


\subsection{Formas de tratamento e análise dos dados coletados para o estudo}

Como explicado anteriormente, para a obtenção de dados foram entrevistadas 16 pessoas, com perfis e idades diferentes, mas que tivessem aspectos em comum, como o costume da leitura e o hábito de compra de livros.

Para esse estudo, a identidade dos entrevistados foi preservada, portanto seus nomes foram alterados para: Entrevistado 1, Entrevistado 2, e assim por diante, visando garantir o anonimato.

Ao obter todos os dados, estes foram analisados, tendo como objetivo interpretar as respostas, obtidas através das entrevistas presenciais e on-line. As entrevistas foram transcritas para um mesmo documento, para serem melhor consultadas e foram analisadas uma a uma.

Para a análise dos resultados utilizou-se duas etapas complementares:

"A primeira, chamada de inter-participantes, consiste na análise das respostas dadas pelo grupo como um todo, enquanto a segunda, denominada intra-participantes, se dedica à análise detalhada de cada uma das entrevistas individuais" (NICOLACI-DA-COSTA; ROMÃO-DIAS; DI-LUCCIO, 2008, p.42).

Na primeira etapa, as respostas foram analisadas e comparadas em busca de recorrências. Estas deram visibilidade aos valores referentes ao grupo que os entrevistados pertencem e deram uma visão geral das respostas obtidas. Num segundo momento, ocorreu a comparação das respostas buscando inconsistências, novos conceitos e por fim foi feito um cruzamento dessas análises para obter melhores resultados. (NICOLACI-DA-COSTA; ROMÃODIAS; DI-LUCCIO, 2008)

\subsection{Limitações do Método}

As principais limitações desse estudo relacionam-se com as desvantagens do método escolhido. A primeira delas é, segundo Malhotra (2002), a falta de estrutura das entrevistas aplicadas, que podem sofrer influências por parte do entrevistador, resultando em respostas não tão genuínas.

Segundo, é difícil analisar e interpretar as respostas dado que as perguntas são abertas e os entrevistados são incentivados a responderem o que acharem pertinente. Além disso, pelo tempo empenhado, número de perguntas e 
respostas abertas, a quantidade de entrevistados é, normalmente, não representativa. (MALHOTRA, 2002).

Buscando minimizar as influências do entrevistador, as análises foram pautadas exclusivamente nas respostas dos entrevistados. Os dados encontrados foram ao mesmo tempo diversos, havendo opiniões diferentes e novos conceitos, mas também homogênea, onde os principais aspectos dos livros impressos foram citados por quase todos os entrevistados.

Outro ponto negativo, é que por grande parte das entrevistas terem sido feitas on-line, há grandes chances de os entrevistados não estarem totalmente focados, podendo se distrair com outras funções da internet. 


\section{Apresentação e análise dos resultados}

Este capítulo está organizado em quatro seções, onde apresenta e discute os principais resultados que foram obtidos em relação ao objetivo do estudo, analisa e discute suas implicações e produz sugestões sobre o estudo previamente selecionado.

\subsection{Perfil dos Entrevistados}

No início da entrevista foram feitas perguntas para a determinação do perfil dos entrevistados, que como mencionado anteriormente, foi delimitado a indivíduos com idade entre 18 a 40 anos, residentes do Rio de Janeiro e que tivessem o hábito de ler obras literárias e o costume de comprar livros.

Todos os entrevistados foram escolhidos por conveniência e seus nomes, foram mantidos em anonimato. A seguir, é exposta a Tabela 1, que apresenta o perfil do entrevistado:

Tabela 1: Perfil dos Entrevistados

\begin{tabular}{|c|c|c|c|}
\hline Entrevistado & Sexo & Bairro & Idade \\
\hline Entrevistado 1 & Feminino & Ilha de Guaratiba & 25 \\
\hline Entrevistado 2 & Feminino & Barra da Tijuca & 22 \\
\hline Entrevistado 3 & Feminino & São Conrado & 23 \\
\hline Entrevistado 4 & Masculino & Barra da Tijuca & 22 \\
\hline Entrevistado 5 & Feminino & Méier & 32 \\
\hline Entrevistado 6 & Feminino & Barra da Tijuca & 22 \\
\hline Entrevistado 7 & Masculino & Botafogo & 33 \\
\hline Entrevistado 8 & Feminino & Tijuca & 27 \\
\hline Entrevistado 9 & Feminino & Copacabana & 22 \\
\hline Entrevistado 10 & Masculino & Barra da Tijuca & 23 \\
\hline Entrevistado 11 & Feminino & Tijuca & 20 \\
\hline Entrevistado 12 & Feminino & Ipanema & 24 \\
\hline Entrevistado 13 & Feminino & Copacabana & 24 \\
\hline Entrevistado 14 & Feminino & Recreio & 22 \\
\hline Entrevistado 15 & Masculino & Flamengo & 40 \\
\hline Entrevistado 16 & Feminino & Tijuca & 20 \\
\hline
\end{tabular}


Foram um total de 16 consumidores entrevistados, dos quais 12 eram mulheres e 4 homens. Todos os entrevistados residem no Rio de Janeiro, dispersos entre as Zonas Sul, Oeste e Norte.

A faixa etária estabelecida foi respeitada, e pode-se analisar que a média etária entre 15 dos entrevistados foi de 24 anos, retirando-se o Entrevistado 15, que possui 40 anos, idade muito divergente do restante da amostra.

\subsection{Frequência de Leitura}

Para analisar a frequência de leitura dos consumidores, foi perguntado se eles possuíam o costume de ler obras literárias e quantos livros haviam lido nos últimos seis meses. Dessa forma, foi realmente possível verificar se existia mesmo o hábito da leitura em suas vidas.

Todos os entrevistados possuíam tal hábito, contudo, seis deles ressaltaram que, pela rotina acelerada e falta de tempo, a frequência diminuiu.

"Eu lia bastante há alguns anos atrás, era um super costume! Depois que a faculdade começou a ficar mais pesada e exigir um pouco mais de mim (e depois que comecei a estagiar também), o ritmo da vida era bem corrido!! Comecei a ficar com muito pouco tempo livre... então posso dizer que nos últimos 6 meses devo ter lido 5 livros." (Entrevistada 2)

Já sobre a quantidade de livros lidos, ponderou-se uma média de cinco durantes os últimos seis meses. Tal número foi encontrado analisando 14 das 16 respostas. Por outro lado, dois entrevistados mostraram que leem muito, sendo que nos últimos seis meses leram mais que cinco livros, como pode ser visto nos depoimentos, a seguir.

“(...) Leio em média de três livros por mês, então isso daria uns 18 livros em seis meses. Antigamente, quando não trabalhava e antes de entrar na faculdade, costumava ler por volta de 10 livros por mês e já cheguei a ler 130 em um ano." (Entrevistada 11) 
“(...) Li 200 livros nos últimos seis meses (sim, leio demais)." (Entrevistada 16)

Portanto, é possível observar que todos os entrevistados apreciam a leitura e praticam o hábito com frequência.

\subsection{Comportamento da Compra}

Para entender melhor o comportamento dos consumidores de livros, a entrevista foi sendo conduzida de forma a coletar dados sobre o que mais motivava um leitor a comprar um livro, quais os atributos analisados no momento da compra, quais eram as principais fontes de influência durante o processo decisório, entre outros hábitos de leitura, que tinham por finalidade entender as preferências e fatores que influenciavam a tomada de decisão.

Como citado no referencial teórico, Solomon (2011) diz que é preciso avaliar o processo de compra como um todo, ou seja, os quesitos que influenciam o consumidor antes, durante e depois da compra. Sem contar as três principais influências do seu comportamento: as sociais, de marketing e situacionais.

É importante entender o que desperta a necessidades desses consumidores, para compreender todo seu processo de tomada de decisão.

\subsubsection{Reconhecimento da Necessidade}

Para começar a entender a tomada de decisão dos consumidores de livros, era necessário, primeiramente, entender como se dava a percepção da necessidade de compra por estes indivíduos. Quais os estímulos, tanto internos, quanto externos (CHURCHIL; PETER, 2007) que despertavam o desejo por comprar um livro.

Com esse objetivo, tentou-se extrair dos entrevistados os motivos pelos quais eles compravam um livro, ou seja, qual era o verdadeiro intuito ao adquirir uma obra literária.

Visto isso, a partir da análise das repostas, existem dois principais estímulos que geram a necessidade de ler um livro, são eles: o entretenimento e o conhecimento.

Todos os entrevistados mencionaram pelo menos um desses dois motivos, se não, os dois. Pela análise é possível perceber que a leitura é uma forma de 
se obter conhecimentos, desenvolver vocabulário, melhorar a capacidade de escrita, e entender pensamentos e perspectivas diferentes. Outro ponto curioso foi que todos os homens que participaram do estudo mencionaram a obtenção de conhecimento como um dos estímulos à leitura.

“Meu principal intuito é obter conhecimento. Entender pensamentos diferentes, abrir a cabeça para questões que não domino. Outras perspectivas"

(Entrevistado 10)

"Procuro me distrair e tentar tirar alguma lição de vida, algo que eu posso acrescentar a minha vida." (Entrevistada 8)

"Diversão, desvendar os mistérios, gosto de livros que me fazem pensar. Trabalhar o pensamento analítico e raciocínio." (Entrevistado 15)

"(...) sem contar que com o passar do tempo, ler te ajuda com questão de vocabulário e articulação de frases." (Entrevistada 2)

Além disso, ler também é uma fonte de distração. Todos os entrevistados mencionaram que o principal intuito de comprar um livro é se entreter e passar o tempo. Alguns vão além, e explicitam que ler é uma forma de escape da realidade, uma maneira de relaxar e poder visitar diversos locais sem sair do lugar. Onde a história é muito importante, precisa ser excitante para impressionar o leitor e prender sua atenção, fazendo com que ele esqueça tudo ao seu redor.

"Me considero uma pessoa sonhadora e bem fantasiosa, existe uma frase, de um livro que eu amo, que fala o seguinte: 'A reader lives a thousand lives before he dies, said Jojen. The man who never reads lives only one.' Isso resume, basicamente, o que eu sinto ao ler. Ler é um escape, é um momento meu. Ler é relaxar ao ponto de me tele-transportar para a história que eu estou conhecendo. 
É viver culturas diferentes, histórias e sentimentos diferentes, vidas diferentes, e por um momento esquecer até mesmo da sua. Ler é uma necessidade. Nada melhor do que um livro que te desliga e que você não consegue parar. “ (Entrevistada 14).

"Eu procuro história empolgantes, quero me sentir parte de contos diferentes, me sentir transportada para locais que eu talvez não consiga ir na minha realidade." (Entrevistada 16)

Outra questão levantada como necessidade percebida foi a percepção de como é feita a estruturação das histórias, a capacidade de uma mesma mente conseguir criar diversas personagens, com características diversas e papéis diferentes.

"É legal ver como um autor pode construir personagens tão reais que dá vontade de conhecer. Eu compro com o intuito de me envolver na história; de ver diferentes pessoas que se encaixam, criadas por uma mesma cabeça (...). " (Entrevistada 12)

Essas necessidades podem ser explicadas pela definição dos tipos de necessidade, definidos por Solomon (2011), as necessidades utilitárias e hedônicas. Pela definição a segunda, está relacionada a "uma necessidade de experiência envolvendo respostas ou fantasias emocionais" (p.154), podendo explicar as citações acima mencionadas.

O desejo do leitor de viver novas experiências e realidades, se transportar para mundos fictícios e desvendar casos policiais, instiga a imaginação e mexe com as suas emoções e seus sentidos, tornando assim, um estímulo à necessidade da compra do livro.

Como foi visto no referencial teórico, Solomon (2011) explica que muitos indivíduos podem ter necessidades semelhantes, entretanto a forma como cada uma será satisfeita, depende das preferências individuais. Portanto, mais de um leitor pode desejar se envolver em uma história e "não conseguir parar de ler". Contudo, para uns o livro perfeito pode ser um suspense policial, com ação de um final surpreendente. Já para outros, pode ser uma fantasia passada em um 
mundo imaginário, onde existem criaturas mágicas. Então seus atributos analisados e escolhas durante o processo decisório serão diferentes.

\subsubsection{Busca de Informações e Avaliação de Alternativas}

Depois de entender os estímulos internos e externos que geraram a necessidade, é preciso entender como tais desejos são satisfeitos. Segundo Churchill e Petter (2007), o processo decisório de compra de um consumidor é determinado pelo envolvimento que ele desprende para determinada compra, a busca que faz por informações externas e internas e as influências que sofre.

Para isso, foram analisadas perguntas que buscavam entender onde os consumidores buscavam informações para embasar suas decisões e quais atributos avaliavam para a tomada de decisão.

Quanto às fontes de informação, todos os entrevistaram mencionaram que fazem algum tipo de busca antes de comprar o livro. Baseando-se na revisão de literatura do presente estudo (CHURCHILL E PETTER, 2007), os entrevistados obtêm dados de três fontes principais:

- Fontes de grupos - por meio de indicações de amigos ou familiares;

- Fontes públicas - através de sites como Amazon.com, resumos/reviews online, listas de livros mais lidos ou mais vendidos e fóruns, onde analisam comentários de outros leitores;

- Fontes de experimentação - através de pesquisas nas próprias livrarias.

Para muitos dos entrevistados a fonte de experimentação é uma das mais valorizadas. Eles acreditam que o processo de compra que envolve ir até a livraria, analisar os atributos dos livros impressos e só assim tomar a decisão é prazeroso. Cinco dos dezesseis entrevistados declararam que preferem 0 método tradicional para obtenção de informações, caracterizando o comportamento dos amantes de livros impressos. Aqueles que estão dispostos a depositar um grande esforço a fim de satisfazer uma necessidade.

"Eu amo livraria, passo um bom tempo dentro delas. Quase o mesmo que numa loja de roupa. Olho tudo, leio o resumo de vaaaaarios e escolho assim. Muito difícil eu pesquisar em qualquer lugar sobre livros. Gosto de passar 
tempo procurando eu mesma e vendo todas as histórias que tem disponíveis. É quase como escolher um sapato, eu tento "experimentar" todos antes de fazer a escolha." (Entrevistada 9)

"Quando não é por indicação ou por boas críticas em revistas e jornais, escolho pela capa e título. Muitas vezes vou à livraria sem livro definido e deixo o título e a capa me chamarem atenção." (Entrevistada 3)

Todos os entrevistados mencionaram a internet como um meio de pesquisa de informações. Três dos entrevistados assumiram usar pouco esse meio de pesquisa, apenas para assuntos específicos e consulta de preços. Para os demais, sites de resumos ou resenhas, blogs e fóruns foram os mais citados.

Contudo, existem aqueles que acreditam que nem todas as fontes de informações são relevantes. No caso das de ordem pública, eles buscam informações sobre o livro, como resumos e opiniões de leitores. Contudo, indicações prêmios recebidos são considerados apenas quando o livro desperta o interesse. Ou seja, os entrevistados não despertam interesse por um livro apenas por este ter sido bem cotado em uma classificação.

“(...) Não compraria um livro ganhador de 1000 prêmios se a sinopse não me animasse, nem leio livro porque todo mundo lê." (Entrevistada 11)

Em relação às fontes de grupo, muitos entrevistados mencionaram ter preferência por livros que tenham sido indicados, pois a chance de "jogar dinheiro fora" é menor.

"Com certeza prefiro indicações, é muito difícil eu arriscar e comprar um aleatório na livraria porque vai me incomodar bastante se eu não gostar! Não gosto de gastar dinheiro/meu tempo à toa, tem que ser bem gasto com algo que me atraia hahaha." (Entrevistada 2)

Analisando especificamente a citação acima, para esta entrevistada, esse seria um motivo para a decepção na etapa de pós-compra, onde o benefício 
percebido seria menor do que os custos envolvidos e a necessidade não é satisfeita (CHURCHILL E PETER, 2007; KOTLER, 2008).

Os outros entrevistados acreditam que gosto é muito pessoal e não gostam de indicações, preferem analisar livros por si mesmos.

"Não ligo para críticas ou indicações, pois cada um pensa de um modo diferente sobre as histórias, então, sempre prefiro escolher por mim mesma." (Entrevistada 16)

Depois de se obter as informações, os consumidores avaliam os atributos da compra que vão ser significativos na escolha do produto final. Segundo Churchill e Petter (2007), eles analisam cada alternativa verificando as características de cada uma e ponderando qual opção trará mais valor a sua compra, ou seja, qual delas atenderá melhor às suas expectativas.

Analisando as respostas obtidas os principais atributos reparados são: sinopse/ história, capa e título. Entretanto, também foram mencionados o preço, opções em língua estrangeira, autor e escrita, prefácio e diagramação.

"Capa e o resumo, sempre! Odeio quando não tem sinopse e só tem os comentários sobre a avaliação de revistas e pessoas importantes. Eu gosto de saber da história antes pra saber se eu vou gostar." (Entrevistada 9)

"Conteúdo, primeiramente, claro. Depois, com certeza o projeto gráfico. Como disse, levo muito em consideração ilustrações, capa, tamanho, tipo de folhas e toda a parte de diagramação também." (Entrevistada 11)

"Com certeza o preço!" (Entrevistada 8)

\subsubsection{Hábito de Leitura}

As perguntas a seguir tiveram a intenção de verificar hábitos de leitura dos entrevistados, para entender melhor seu comportamento de compra. Como, por exemplo, o gênero literário favorito ou locais onde costumam ler.

A grande maioria dos entrevistados teve dificuldade em escolher apenas um gênero literário favorito, mencionando dois ou mais estilos que apreciavam 
ler. O mais citado foi o Romance, seguido de Suspense, depois Fantasias e Policiais. Também foram citados livros sobre Política/História, Biografias e Business, sendo estes mencionados por apenas duas pessoas.

Os leitores optam por estilos que atendam seus interesses, que os remetam ao escapismo, mencionado anteriormente, a realidades diferentes das que se encontram e a histórias que prendam a atenção.

"Romance. É o gênero que eu prefiro porque são histórias que me envolvem, me fazem sentir: ficar triste, feliz ou até mesmo chorar." (Entrevistada 3)

"Gosto mais de livros sobre política ou história. Esses temas sempre me interessaram, pois acho legal entender os fatos por trás dos principais acontecimentos." (Entrevistado 7)

"Gosto muito de fantasias de qualquer tipo, urbanas, épicas, em mundos fictícios ou reais. Acho que é a coisa do escapismo mesmo, de ler sobre algo impossível, tão diferente da vida normal. Admiro muito autores que conseguem criar histórias complexas e todo um universo, como acontece com Harry Potter e Game of Thrones, por exemplo." (Entrevistada 11)

"Policial e suspense. Adoro histórias de mistério e suspense e ver até onde vai minha capacidade de dedução dos crimes ou mistérios." (Entrevistado 15)

A leitura não tem lugar certo para acontecer. Como foi visto anteriormente, é uma boa forma de lazer e passatempo, e pelo livro ser um objeto, muitas vezes pequeno, pode ser transportado para qualquer lugar. Dessa forma, é muito utilizado para aproveitar o tempo gasto em engarrafamentos, por exemplo. Hoje, os leitores contam com aparelhos digitais chamados e-readers, para a leitura de livros digitais (BOTTENTUIT JUNIOR; COUTINHO, 2007; PREMISSAS, 2010). Ele tem sido muito adquirido por pessoas que gostam de carregar seus livros consigo em caso de um tempo vago para ler. 
Quando perguntados sobre onde tinham o costume de ler, a maioria respondeu o conforto do próprio lar, com 13 citações. Entretanto, os leitores também costumam ler no transporte público, na praia, em viagens e avião, e cafés.

"TODOS os lugares, literalmente! Viagens, no trânsito, em casa, até no trabalho por 15 minutos no almoço. Para mim não tem lugar pra ler." (Entrevistada 9)

"Eu leio basicamente em dois momentos: 1) ida/volta do trabalho 2) antes de dormir" (Entrevistada 6)

Um ponto levantado era a comodidade de levar seus livros em viagens, todos os entrevistados mostraram gostar de levar um livro consigo, mesmo que venham a não ler. Além disso, muitos não se incomodavam de levar livros impressos, enquanto outros, visando a praticidade e economia de peso, optaram por e-readers, para manter o hábito da leitura.

"Eu costumo, sim. Em viagens eu gosto muito de ler livros. Eu levava muito livro, mas agora eu levo kindle né, que eu prefiro." (Entrevistado 4)

Analisando o restante das perguntas, 14 entrevistados não possuem o hábito de ler mais de um livro por vez. Quando lêem um livro, gostam de se envolver com a história, depositando tempo e concentração em apreciá-la. O fato de misturar dois livros foi considerado confuso e criticado por alguns.

Entretanto, as duas maiores leitoras do estudo, que tinham uma média de 18 e 200 livros lidos nos últimos seis meses, tinham visões divergentes. Para a primeira, essa foi uma prática adquirida com o tempo e atualmente consegue administrar a leitura de aproximadamente três livros por vez. Entretanto, não aconselha a prática. Já para a segunda, essa opção não é considerada, gosta de depositar sua atenção para um livro por vez.

Para a etapa final de decisão de compra do processo decisório, em que o consumidor pondera sobre qual produto comprar, onde comprar, quando comprar e quanto ou como pagar (CHURCHILL E PETER, 2007), as opiniões ficaram bem divididas quanto a onde comprar. A grande maioria opta por meio online, como internet ou nos próprios leitores digitais. Entretanto, a escolha de 
sites de compra é muito influenciada pelas promoções e preços mais em conta que os encontrados nas livrarias. Boa parte, ainda prefere fazer a compra pessoalmente para apreciar todo o processo de compra e o ambiente das livrarias, mas acaba cedendo às ofertas online.

Os consumidores consideram que a compra presencial é mais gratificante e é possível analisar, com calma e qualidade, os atributos dos livros. São aqueles tem um envolvimento maior durante o processo de compra, que dispõe de um alto grau de esforço, pois busca entender e analisar todas as características do produto. Já os usuários de leitores digitais, frisam a praticidade e comodidade em poder ter o livro na hora que desejar, sem precisar sair de casa para obter um livro ou esperar entregar, onde o esforço envolvido é baixo.

Quanto ao preço que estavam dispostos a pagar, a maioria manteve-se na faixa de $R \$ 20$ a $R \$ 30,00$, não estando dispostos a passar desse limite. Em casos especiais, alguns se dispõem a pagar até $\mathrm{R} \$ 60,00$. Mas o ponto principal é que tanto para livros digitais quanto físicos a diferença de preço não é grande.

Os usuários de e-readers gastam em média $R \$ 20,00$ para obter seus livros, salvo casos de promoções. Levando em consideração que os e-books tem um custo de produção reduzido se comparado aos livros impressos, que tem todo o processo de edição, produção e entrega, pode-se perceber que o custobenefício não se comprova, na visão dos entrevistados.

\subsection{Livros Impressos $x$ Livros Digitais}

O presente estudo tem como objetivo analisar as motivações para a compra de livros impressos e digitais, as preferências de leitura e pontos positivos e negativos dos dois tipos de livros. De forma geral, busca compreender o perfil do consumidor de livros frente o mercado atual. Sabe-se que com a evolução das tecnologias os e-readers tem ganhado espaço (MESQUITA; CONDE, 2008), mas o livro impresso ainda é, no Brasil, o preferido dos leitores (BRITTO, 2013).

Então, nessa seção da entrevista, procurou-se compreender a escolha dos leitores entre os livros impressos e digitais, verificando quais os fatores que eram levados em consideração para tomada de decisão e analisando a visão que tinham sobre cada tipo de leitura.

A principal questão foi pedir aos entrevistados que escolhessem entre livro impresso e digital, dando uma justificativa. 
"Impresso, com certeza! Acho muito legal como a gente pode ter uma relação super pessoal com o livro, a sensação de comprar um novo, sentir o cheiro dele, ter ele em nossas mãos, virar as páginas... pode soar meio estranho mas fazem parte da essência que é ler um livro!!" (Entrevistada 2)

"Digital. É prático, sincroniza automaticamente no celular e no notebook, e é ecologicamente mais correto (menos árvores derrubadas)." (Entrevistado 7)

O resultado encontrado mostra que de um total de dezesseis leitores, treze preferem o livro impresso e apenas, três optaram pelas versões digitais. Os leitores enaltecem que nada supera a experiência de ler um livro tradicional. $O$ contato mais pessoal entre livro e leitor faz parte do processo de ler um livro. Ou seja, o ato de ler envolve muito mais que apenas o conteúdo. Envolve a relação pessoal que se tem com o objeto livro, como passar as páginas, sentir o livro nas mãos, fazer marcações e anotações, sentir o cheiro e usar marcadores de página. Sem falar dos outros atributos mencionados anteriormente, como, por exemplo, a capa e título. Esses resultados estão de acordo com o que Darnton (2010) observou: os livros foram feitos para serem folheados, que "é um prazer para os olhos" e onde a sua forma "torna o ato de segurá-lo nas mãos um deleite". (p.86)

Dos treze entrevistados, apenas dois nunca leram um livro digital e dizem não ter vontade de experimentar. Dos onze restantes, cinco não gostaram da experiência ou não se adaptaram, enquanto os outros seis se surpreenderam positivamente.

"Li, pelo kindle de uma amiga. Eu detestei, achei desconfortável, não me deu o prazer que o livro físico me dá." (Entrevistada 16)

"Sim, leio sempre. Utilizo o Kindle e acho a experiência incrível, tive dúvidas se iria me adaptar no começo, sempre fui defensora ferrenha dos livros físicos, mas assim que ganhei o Kindle percebi que os dois não são inimigos e ele só me fez ler mais ainda." (Entrevistada 11) 
Vale ressaltar que o discurso da Entrevistada 11 vai ao encontro do que autores relataram: que os livros físicos e digitais podem ser vistos como complementares e não como inimigos (PREMISSAS, 2010).

Do total que escolheu as obras tradicionais, cinco pessoas não são adeptas desse tipo de livro. Utilizando, e-readers como principal meio de leitura, mas preferem o livro tradicional, pela experiência global da leitura, que engloba não só o conteúdo como o ato de ler.

"Pela experiência global da leitura, que para mim não engloba apenas o conteúdo, o livro físico. Nada se compara ao toque das folhas, o cheiro, ir fazendo marcações a lápis, etc.(...) Porém, hoje em dia sou adepta do livro digital. Gosto do fato de poder levar todos os meus livros de uma vez dentro de um aparelho pequeno e leve." (Entrevistada 11)

De forma geral, os entrevistados percebem hoje os livros impressos como opção melhor e mais pessoal de ler livros. Por mais que as vantagens dos livros digitais sejam reconhecidas (PREMISSAS, 2010; BRITTO, 2013), seus atributos não superam o meio tradicional. A grande maioria dos entrevistados prefere abrir mão da praticidade pelo costume de sentir o livro.

No final das entrevistas os consumidores foram questionados sobre os pontos positivos e negativos dos dois tipos de livro sob seu ponto de vista. A entrevista em si e todos os temas que haviam sido abordados auxiliaram na organização das percepções e preferências dos entrevistados.

A Tabela 2, a seguir, apresenta os principais pontos positivos listados pelos entrevistados em relação a livros impressos e livros digitais.

Tabela 2: Pontos positivos dos livros impressos e digitais

\begin{tabular}{|c|c|}
\hline \multicolumn{2}{|c|}{ Pontos Positivos } \\
\hline Livros Impressos & Livros Digitais \\
\hline Objeto em si & Praticidade \\
\hline Relação de proximidade & Leveza \\
\hline "Ter o livro nas mãos" \\
$\begin{array}{c}\text { Folhear páginas/ fazer } \\
\text { anotações/ usar marcadores de } \\
\text { página }\end{array}$ & Livro mais barato \\
\hline Capa & Conectividade \\
\hline
\end{tabular}




\begin{tabular}{|c|c|} 
Tradição & Milhões de livros num aparelho \\
\hline Maior atenção/foco à história & $\begin{array}{c}\text { Compra de livros em tempo } \\
\text { real }\end{array}$ \\
\hline Fácil Manuseio & $\begin{array}{c}\text { Acesso fácil a número maior } \\
\text { de livros }\end{array}$ \\
\hline Item de Decoração & Arquivos não são pedidos \\
\hline Melhor para visão & Menos desperdício de papel \\
\hline Poder doar /emprestar o livro & $\begin{array}{c}\text { Bom para histórias maiores } \\
\text { (livros grandes) }\end{array}$ \\
\hline Imagens e gráficos & Leitura mais rápida \\
\hline
\end{tabular}

Para os leitores a principal vantagem do livro físico é o objeto em si. Poder tê-lo nas mãos aumenta a relação de proximidade com o objeto e torna a experiência da leitura mais pessoal. Conceitos visto também nas declarações de Darton (2010). Em um mundo onde as tecnologias e aparelhos eletrônicos fazem parte constante do dia a dia das pessoas, os leitores acreditam que é importante conseguir se desligar um pouco e fazer uma atividade longe de telas e carregadores. Como mencionado na resposta da Entrevistada 5:

"Prefiro o livro impresso pelo ritual mesmo. Aquela coisa de você relaxar. O aparelho eletrônico te dá mais a sensação de que você não saiu do celular, do computador..." (Entrevistada 5)

Além disso, os aspectos externos do livro também são muito importantes. Poder escolher e analisar as capas e suas diferentes impressões, todo o projeto gráfico do livro. Além é claro, de poder ser usado como decoração e coleção e o ato de poder doar ou emprestar a outras pessoas.

"Ultimamente tenho visto capa também, porque como existem muitas adaptações cinematográficas eles acabam relançando com a capa do pôster né." (Entrevistada 2)

No caso dos livros digitais, foi unânime a menção da praticidade como principal ponto positivo. Todos os leitores compreendem que os livros digitais, principalmente quando disponibilizados em e-readers ou tablets, dão ao leitor a possibilidade de levar consigo diversas obras ao mesmo tempo, sem carregar um peso absurdo. Oferecer acesso a um número maior de livros, tanto em outros idiomas quanto a edições difíceis de encontrar ou que pararam de ser 
impressas. Outro importante ponto citado foi a facilidade do processo de compra, feito em tempo real a partir de um clique. O limite de tempo gasto para baixar um livro em um kindle, por exemplo, é de sessenta segundos. (PREMISSAS, 2010).

"Você poder andar com milhões de livros num negocio desse tamanho. O tamanho dele é muito bom. Você poder comprar, ele automaticamente. Tipo to afim de ler um livro? Eu vou lá, compro e baixo ele aqui. Não preciso esperar entregar, não preciso sair de casa pra comprar." (Entrevistado 4)

Além disso, a conectividade também foi bastante mencionada. Quando se possui um e-reader existem diversas funcionalidades que facilitam o entendimento da leitura e conectam o leitor ao mundo digital, como poder compartilhar quotes do livro. Contudo, nem todos os leitores estariam dispostos a comprar um leitor digital pelo alto custo que ainda possuem no Brasil, sendo que a grande que já possui obteve fora do país.

"Encontrei um Kobo (isso fora do Brasil) em ótima promoção e resolvi comprar." (Entrevistada 13)

Um ponto que foi levantado apenas por dois entrevistados foi a questão da consciência ecológica, visto que com os livros digitais o gasto de papel usado nas impressões dos livros é reduzido. Pode-se analisar então, que essa questão não é muito levada em consideração quando o leitor opta pelo tipo de livro.

A Tabela 3, a seguir, apresenta os pontos negativos abordados pelos entrevistados em relação aos livros físicos e livros digitais.

Tabela 3: Pontos negativos dos livros impressos e digitais

\begin{tabular}{|c|c|}
\hline \multicolumn{2}{|c|}{ Pontos Negativos } \\
\hline Livros Impressos & Livros Digitais \\
\hline Espaço ocupado & Ler numa tela \\
\hline Preço & Necessidade de bateria \\
\hline Não resistentes & $\begin{array}{l}\text { Dificuldade para passar } \\
\text { paginas }\end{array}$ \\
\hline Peso & Formatação (figuras) \\
\hline & Ipad - ruim para visão \\
\hline
\end{tabular}




\begin{tabular}{|c|} 
Falta da magia do papel \\
\hline Preço ainda elevado \\
\hline Falta de concentração \\
\hline
\end{tabular}

O principal ponto negativo dos livros impressos, levantados pelos entrevistados, foi o peso. Por mais que a experiência de ler um livro físico seja melhor para a maioria dos leitores, muitas vezes o trabalho empregado para desfrutar da sua leitura em locais públicos, que demanda o transporte do livro é desmotivador. Outro ponto ressaltado é o espaço ocupado. Quando se tem o hábito de ler com freqüência livros impressos, é demandado um grande espaço para guardar todas as obras. Contudo, esse fato foi contestado por alguns entrevistados. Para eles isso é uma questão a se debater, visto que os livros podem ser considerados artigos de decoração, como mencionado pela Entrevistada 6.

"O espaço. Mas também depende do ponto de vista né, você pode ver como o livro ocupa um espaço ou aquele espaço esta sendo bem ocupado né. Fica bonito até para decoração, como disse antes fica Cult." (Entrevistada 6)

Os outros dois pontos levantados foram os preços, que são mais elevados e a resistência. Esta que pode ser afetada por fatores como tempo, desgaste, falta de cuidado ao manusear, entre outros.

Analisando os livros digitais, os entrevistados listaram como desvantagens utilizar um aparelho digital para leitura, ou seja, não conseguir se desvencilhar das tecnologias. Em alguns casos, como no da leitura em tablets a agressão da visão pela luz imprópria à leitura. Já na leitura em e-readers foi ressaltado a dificuldade em passar as páginas e saber quanto falta para terminar o livro. 0 medo de utilizar tais aparelhos em "qualquer lugar", como transporte público, e sofrer um assalto, foi, uma outra visão levantada pelos leitores.

Outro ponto mencionado foi a questão da bateria. Por mais que tenha duração de 30 a 40 dias, necessita de energia para ser carregada, sem contar que é "mais um carregador na bolsa", como menciona a Entrevistada 9:

"O digital é a falta da magia do papel e ter que carregar o carregador toda vez que viaja, mais um cabo pra coleção." (Entrevistada 9) 
Os entrevistados que tinham preferência pelos livros impressos, quando questionados sobre o que faria eles optarem pelos digitais, responderam que só o fariam em raras ocasiões, como, por exemplo, não encontrarem um livro muito desejado em outro formato. Além disso, a falta de espaço e obras voltadas para estudo foram outros motivos destacados. Houve também respostas mais extremas, como a da Entrevistada 2, que afirmou só optar por esse tipo de leitura caso as editoras encerrassem as impressões de livros físicos.

$$
\begin{aligned}
& \text { "Acho que caso as editoras encerrem as atividades e } \\
& \text { parem de publicar livros." (Entrevistada 2) }
\end{aligned}
$$

Para os que preferiam livros digitais, a obra física só seria uma opção caso fossem parte de uma coleção ou edição especial, e/ou serie ou autor preferidos. Eles também escolheriam o livro impresso como forma de presentear alguém.

Para finalizar a entrevista, os leitores deveriam dar sua opinião sobre uma questão que tem sido tema de discussão desde que os livros digitais surgiram: "Você acha que o livro digital irá substituir os livros físicos?". Para a grande maioria a resposta foi não.

Muitos enfatizaram que o livro impresso não pode ser substituído, sua riqueza e materialidade são importantes para o ser humano e aqueles que realmente apreciavam a experiência de ler nunca deixarão de comprar livros físicos. Disseram ainda, que existe muito mercado para os livros impressos, outros foram além e mencionaram que um não precisa parar de existir para que o outro cresça, podendo co-existir e, também, se complementar. Como no caso da Entrevistada 9, que utiliza os dois tipos de livros em situações diferentes:

"Eu leio dos dois jeitos. E depende muito da situação. Eu gosto de livro impresso, mas muitas vezes é mais prático usar o kindle." (Entrevistada 9)

Para outros, a substituição era um termo forte de se usar, mas acreditavam que com o passar do tempo o consumo desse tipo de livro iria sim, diminuir. Principalmente, porque as novas gerações já estão sendo criadas nessa nova era digital.

Apenas um entrevistado respondeu que acreditava que os livros físicos iriam acabar, ressaltando como motivos a praticidade e consciência ecológica dos digitais. 


\section{Conclusões e recomendações para novos estudos}

O livro vem sofrendo diversas evoluções ao longo dos séculos, sendo as versões digitais sua mais nova transformação. Com isso, o mercado literário hoje está vivenciando mudanças na forma em que a leitura é consumida, entretanto nem todos os leitores se sentem confortáveis com essa nova realidade. Afinal, o livro de papel tem sido o mais importante meio de transmissão de idéias e conhecimentos ente povos e gerações, além de representar a tradição da leitura, ou seja, a forma original de se praticar a leitura.

O presente estudo teve como objetivo compreender o comportamento do consumidor de livros, por meio da análise de seus hábitos de leitura, processo decisório e preferências. Para isso, foi utilizada uma pesquisa exploratória, com abordagem qualitativa. Onde para obter dados foram feitas 16 entrevistas em profundidade, com leitores habituais, moradores do Rio de Janeiro com faixa etária entre 18 a 40 anos.

Ao analisar os motivadores dos entrevistados para a compra de livros, chegou-se a conclusão de que os principais são a busca por entretenimento e conhecimento. Os leitores vêem os livros como fonte de lazer e enriquecimento cultural. Além disso, a maioria dos entrevistados utiliza a leitura como uma forma de escape da realidade, tendo a necessidade de vivenciar novas realidades e experimentar emoções diferentes. Outro fator importante foi o envolvimento com a história, que para a grande maioria é o que torna a leitura mais prazerosa por prender a atenção e fazer com que o mundo ao redor seja esquecido.

A partir da necessidade percebida, os leitores utilizam diferentes formas de satisfazê-las. Primeiramente, obtêm informações e as três principais fontes usadas são as de grupo, pública e de experimentação. Onde procuram através de indicações de amigos, ou resumos na internet, dados para tomarem sua decisão. Para alguns o processo é mais complexo, por se envolverem muito com o processo de compra, optam por obter dados a partir da experimentação, indo às livrarias e pesquisando todos os atributos de diversos livros. Entretanto, independente da fonte utilizada, foi verificado que todos os leitores pesquisam sobre o livro antes de comprá-lo. 
Através das análises, pode-se perceber que os principais atributos avaliados para a compra foram a sinopse ou a história do livro, a capa e o título. Sendo o preço e autor itens também levados em conta.

Como foi visto, mesmo os leitores tendo necessidades semelhantes, os modos como as satisfazem é muito diferente e influenciado pelas preferências pessoais. Sendo assim, ao analisar os atributos irão optar por histórias que chamem a atenção e se relacione com suas preferências. Sendo os principais gêneros literários procurados: o romance, seguido de suspense e depois fantasia.

Para a tomada de decisão final da compra, os leitores ficam divididos. Grande parte opta por meios online pela praticidade, comodidade e promoções. Entretanto, existem aqueles que não abrem mão da experiência da compra presencial por acreditar ser mais gratificante. Estes preferem fazer a compra diretamente em livrarias, por poder escolher seus livros com calma e apreciar o ambiente ao redor.

Em relação ao hábito de leitura dos entrevistados, pode-se perceber que por procurarem principalmente se entreterem, costumam ler em diversas ocasiões do seu dia e em locais diferentes. A preferência foi pela leitura em casa, mas grande parte também gosta de ler ambientes ao ar livre, como a praia, ou nos transportes públicos.

Já quanto à preferência entre livros impressos e digitais, treze dos dezesseis entrevistados escolheram as obras tradicionais, enquanto apenas três as digitais. Essa preferência pelo livro físico pode ser explicada pelas suas características materiais. O contato mais próximo com o livro foi um dos motivos mais citados pelos entrevistados, que acreditam que a leitura envolve bem mais que apenas o conteúdo. Toda a experiência de sentir o livro nas mãos, folheá-lo e passar as páginas são alguns dos fatores que envolvem o leitor. A tradição e costume também podem ser citados na hora de explicar a preferência.

Viu-se também que apenas dois dos dezesseis entrevistados nunca leram livros digitais, seja em e-readers, computadores ou tablets. Para aqueles que já leram, mas ainda assim optam pela versão impressa, a experiência foi positiva. Um fator de surpresa em muitos casos, devido às fortes resistências que relataram ter à essa nova versão do livro.

Por fim, avaliando os pontos positivos e negativos de cada tipo de livro, pode-se concluir que:

Como pontos positivos dos livros impressos pode-se citar o objeto em si, a relação de proximidade, o fato de "ter o livro nas mãos", e a escolha da capa 
como principais vantagens. Já sobre os pontos negativos, observou-se o peso, espaço ocupado e preços mais elevados.

Sobre os livros digitais, os pontos positivos ressaltados foram a praticidade, facilidade da obtenção de livros e conectividade. Já sobre seus pontos negativos, os mais citados foram ser um aparelho digital, ou seja, não conseguir se desconectar do mundo digital, não ter a sensação de estar lendo um livro de verdade, e principalmente a dificuldade de passar as paginas, e a forma de carregar o aparelho.

Assim, pode-se observar que o processo de compra dos consumidores de livros entrevistados é similar, pois todos procuram informações antes de fazer a compra e utilizam a internet ou as livrarias como fonte de informação e de compra. Os fatores que mais diferem são em relação à preferência de compra.

Além disso, a grande maioria concorda que por mais que os livros digitais ganhem espaço nos próximos anos, será por praticidade e não preferência. As versões digitais ainda são vistas como forma de complementação da leitura e não como concorrentes às versões impressas. Através das análises percebemos também que para os entrevistados, o livro impresso não pode ser substituído. A experiência de ler da maneira tradicional é o que mais encanta os leitores e um dos motivos que, segundo estes, o livro físico irá sobreviver frente às evoluções tecnológicas.

O presente estudo é importante para as empresas e profissionais do ramo literário, pois expõe preferências e hábitos de compra dos consumidores de livros. Ainda é possível verificar os principais motivos pelos quais os leitores escolhem um tipo de livro frente a outro.

Para o âmbito acadêmico, é importante, pois a compra de livros ainda é um tema pouco explorado. Tendo poucos estudos que abordem 0 comportamento do consumidor, suas preferências e pontos de vista.

\subsection{Sugestões e recomendações para novos estudos}

Depois da análise da presente pesquisa é possível identificar algumas possibilidades de estudos futuros. Essa linha de pesquisa pode ser estendida através de investigação mais profunda do comportamento do consumidor de livros frente os sites de vendas. Como foi percebido no presente estudo, a compra online é um dos principais meios para se obter um livro. Sendo escolhido, principalmente, pelas promoções. Sendo assim, os profissionais de 
marketing podem investigar a fundo quais são os atributos percebidos pelos consumidores ao pesquisar um livro.

Outro desdobramento possível é explorar como os livros vendidos em livrarias são promovidos. Ou seja, através do comportamento de compra dos leitores em livrarias é possível verificar como eles analisam os livros. Além disso, também é possível verificar fatores que façam com que o ambiente seja convidativo, fazendo com o leitor passe mais tempo dentro das livrarias e, se isso, conseqüentemente é positivo para as vendas.

E, por fim, a pesquisa pode auxiliar o aprofundamento do estudo do processo decisório, tendo enfoque para a etapa de pós-venda. Tendo como objetivo entender como é possível medir a satisfação dos leitores depois de terem efetuado a compra. 


\section{Referências Bibliográficas}

COSTA, A. L. S.; ALBUQUERQUE, C. A.; SALLES, M. A. Avaliação do Processo de Decisão de Compra de Amaciante de Roupas - Marca Própria ou Tradicional na Cidade de Juiz de Fora / MG. XXXI Encontro da Anpad. Rio de Janeiro, 2007.

REIMÃO, S. Estudos sobre produção editorial e história dos livros no Brasil algumas observações. I Seminário Brasileiro sobre Livro e História Editorial. Rio de Janeiro, 2004.

PORTO, R. M; MIOTTO, A. P. S. C. Integrar ou Separar Lojas Físicas e Virtuais? A Estratégia Clicks-and-Mortar no Varejo de Livros. XXXII Encontro da Anpad. Rio de Janeiro, Anpad, 2008.

RAMOS, S. C.; SANDER, J. A.; PRADO, P. H. M. Processo Decisório para Escolha de uma Instituição de Ensino Superior: Dimensões da Decisão e Fatores Relevantes. XXXVII Encontro da Anpad. Rio de Janeiro, 2013.

MENDES, M. E. P. Processo de decisão de compra e estratégias de publicidade. REAd: Revista Eletrônica de Administração. Edição 08 Vol. 4 No. 1, jul-ago 1998.

SOLOMON, M. R. O comportamento do consumidor: comprando, possuindo e sendo. 9 Ed. Porto Alegre: Bookman, 2011.

MALHORTA, Naresh K. Pesquisa de marketing. Porto Alegre: Bookman, 2001.

KOTLER, Philip; KELLER, Kevin Lane. Administração de Marketing. 12ª Ed. São Paulo: Pearson Prentice Hall, 2012.

NICOLACI-DA-COSTA, A.M.; ROMAO-DIAS, D.; DI LUCCIO, F. Uso de Entrevistas On-Line no Metodo de Explicitacao do Discurso Subjacente (MEDS). Psicologia: Reflexao e Critica, 22(1), 36-43. Rio de Janeiro, 2008.

CHURCHILL, G.A. Jr.; PETER, J.P. Marketing: criando valor para o cliente. Sao Paulo: Saraiva, 2007.

DARNTON, R. A questão dos Livros: Passado, Presente e Futuro. Companhia das Letras, 2010.

KOTLER, P.; ARMStRONG, G. Princípios de Marketing. PRENTICE HALL BRASIL, 2008.

PREMISSAS, REVISTA (2010) A Era dos Livros Digitais. Disponível em http://www.periodicos.ufgd.edu.br/index.php/premissas/article/viewFile/841/505.

PORTELLA, E. (2003). Reflexões sobre os caminhos dos Livros. Editora Moderna.

BRITTO, J. (2013). O Avanço dos Livros Digitais. Disponível em: 
http://www.abrale.com.br/?p=3737.

CALDEIRA, C. (2002) Do papiro ao papel manufaturado. Disponível em: http://www.usp.br/espacoaberto/arquivo/2002/espaco24out/vaipara.php?materia $=0$ varia

SOUSA, R. Origem dos livros. Disponível em: http://www.historiadomundo.com.br/curiosidades/origem-dos-livros.htm

SANTOS, K. R. (2010) A evolucao do suporte material, do livro ao E-book: mudancas e impactos ao leitor contemporâneo. Disponível em: http://go.galegroup.com/ps/i.do?p=AONE\&u=capes\&id=GALE|A372958522\&v=2. $1 \& \mathrm{it}=\mathrm{r} \&$ sid=summon\&userGroup=capes\&authCount $=1$

MESQUITA, I. A evolução gráfica do livro e o surgimento dos e-books. Disponivel em:

http://www.intercom.org.br/papers/regionais/nordeste2008/resumos/R12-06451.pdf

HART, M. O Projeto de Gutemberg. Disponível em:http://www.gutenberg.org/wiki/PT-

PG_Hist\%C3\%B3ria_e_Filosofia_do_Project_Gutenberg\%2C_por_Michael_Hart

MOURA,J.; POSSARI, L.H. Do livro impresso ao e-book: a transição do papel para 0 virtual. Disponível em: http://www.editora.ufmt.br/download/ebook_SEMIOSES.pdf\#page=54

MACIEL, N. Correio Brasiliense. (2015) Mercado de livros diminui 8,5\% no Brasil; especialistas garantem que preço não é motivo. Disponível em: http://divirtase.uai.com.br/app/noticia/arte-e-

livros/2015/06/16/noticia_arte_e_livros,168730/venda-de-livros-diminui-8-5-

preco-nao-e-motivo-dizem-especialistas.shtml 


\section{Anexo 1}

O roteiro de entrevista utilizado nesta pesquisa está exposto abaixo:Qual seu sexo?

1. Onde você mora?

2. Quantos anos você tem?

3. Você tem o costume de ler? Se sim, quantos livros leu nos últimos seis meses?

4. Qual gênero literário é o seu preferido/você tem mais costume de ler? Por quê?

5. Como você escolhe um livro para ler?

6. O que você analisa em um livro antes de comprá-lo?

7. Você prefere ler livros que tenham sido indicados por amigos ou tenham recebido boas críticas?

8. Antes de comprar um livro você pesquisa sobre ele? Onde? O que pesquisa?

9. O que você procura em um livro? Tipo por que você compra um livro, com que intuito?

10. Onde costuma ler livros?

11. Você costuma levar livros em viagens?

12. Você lê mais de um livro por vez?

13. Onde costuma comprar seus livros?

14. Quanto paga em média em um livro?

15. Que tipo de livro você prefere, impresso ou digital? Por quê?

16. Já leu algum e-book? Onde, através de um e-reader? O que achou da experiência?

17. Quais são os pontos positivos dos livros impressos? E dos digitais?

18. Quais são os pontos negativos dos livros impressos? E dos digitais?

19. O que faz/faria você comprar um livro impresso?

20. O que faz/faria você comprar um livro digital?

21. Você acha que o livro digital irá substituir os livros físicos? Por quê?

22. Gostaria de acrescentar mais alguma coisa à entrevista? 